Doc. dr. sc. Nikola Vranješ, Teologija u Rijeci, Područni studij Katoličkoga bogoslovnog fakulteta Sveučilišta u Zagrebu, Omladinska 14, 51000 Rijeka, Hrvatska, nickvranjes@yahoo.com

\title{
Elementi, etape i perspektive pastorala braka i obitelji prema apostolskoj pobudnici Amoris laetitia
}

\author{
Nikola VRANJE ̌́ \\ UDK: 272-732.2-452Franciscus, papa • Pregledni članak \\ Primljeno: 23. studenoga 2016. • Prihvaćeno: 27. veljače 2017.
}

Sažetak: Ovaj rad posvećen je teološko-pastoralnoj razradi pitanja pristupa elementima, etapama i perspektivama pastorala braka i obitelji u postsinodalnoj apostolskoj pobudnici pape Franje Amoris laetitia, pri čemu se posebna pozornost posvećuje i temi bračne i obiteljske duhovnosti. Pastoral braka i obitelji jedno je od danas najbremenitijih područja crkvenoga djelovanja. Papa Franjo ga u toj pobudnici sagledava iz šire perspektive uokvirujući ga u suvremeni društveni i pastoralni kontekst. Pri tome Papa obraduje i odredene, mogli bismo ih nazvati, prioritetne zadaće koje je Crkva danas pozvana snažnije aktualizirati $u$ tom području svoga djelovanja. U odnosu na elemente, etape i perspektive pastorala braka i obitelji te na obiteljsku duhovnost te zadaće i prioritete u ovome radu sagledavamo prateći red $i$ dinamiku razrade tema prisutnih $u$ samoj pobudnici, imajući pritom pred očima i neke od izazova iz hrvatske pastoralne situacije.

Ključne riječi: pastoral, brak, obitelj, priprava, duhovnost, Crkva, papa Franjo.

\section{Uvod}

Apostolska postsinodalna pobudnica pape Franje Amoris laetitia i prije nego što je bila objavljena pobudila je veliko zanimanje u crkvenoj, ali i široj javnosti. Nakon njezina objavljivanja o njoj su se s raznih strana mogla čuti različita razmišljanja, i u teološkim i u drugim unutarcrkvenim, ali i izvancrkvenim krugovima. Gledano iz teološko-pastoralne 
perspektive, riječ je, zasigurno, o vrlo vrijednom dokumentu koji donosi niz novih uvida u problematiku pastorala braka i obitelji, kao što nudi i niz poticaja za unaprjeđenje toga tako važnoga, a u isto vrijeme tako bremenitoga područja crkvenoga djelovanja. K tomu, ta pobudnica obiluje teološkim produbljivanjima te na njima sazdanim teološko-pastoralnim prijedlozima vezanim za pristup nekim od najaktualnijih pitanja pastorala braka i obitelji.

U ovome radu posvećujemo se teološko-pastoralnoj razradi glavnih elemenata i etapa pastorala braka i obitelji, kao i sagledavanju perspektiva za njegov razvitak prema onome što je papa Franjo predložio u toj pobudnici. Te su teme u pobudnici na poseban način obrađene u njezinu šestom poglavlju naslovljenom Neke pastoralne perspektive. Moglo bi se reći da je u tom poglavlju obrađeno ono najbitnije s obzirom na ključne elemente i etape pastorala braka i obitelji, dok se u drugim poglavljima razrađuju pojedinačne bitne teme. Zato se i mi u ovom radu u prvome redu posvećujemo proučavanju šestoga poglavlja te pobudnice, pri čemu promišljanja nastojimo što više povezati i s ostalim dijelovima toga dokumenta koji je po sebi vrlo bogat te koji je, kako to i sam Papa u Uvodu ističe, ${ }^{1}$ najbolje iščitavati pristupajući poglavljima kao određenim zasebnim, ali međusobno povezanim cjelinama, kako bi se dobio što bolji uvid u cjelinu dokumenta. Pri tome, jasno, cjelokupnu tematiku pokušavamo sagledavati u sklopu cjelokupnoga naučavanja pape Franje.

Drugo važno težište naših promišljanja ovdje vezano je uz temu bračne i obiteljske duhovnosti koja se u tom dokumentu na poseban način obrađuje u njegovu završnom, devetom poglavlju naslovljenom Bračna i obiteljska duhovnost. I toj temi prilazimo na sličan način kao i prethodno, gore spomenutim temama; pod posebnim vidom zaustavljamo se na devetom poglavlju pobudnice nastojeći što više sagledati ga u cjelini dokumenta.

Promišljanja ovdje iznesena obilježena su nastojanjem da taj vrijedan dokument teološko-pastoralno promotrimo u smislu aktualizacije u konkretnom pastoralnom i društvenom kontekstu. To znači da složenoj problematici pastorala braka i obitelji u pobudnici Amoris laetitia prilazimo tako da proučimo neka najaktualnija pitanja pokušavajući ih sagledati u odnosu na konkretnu pastoralnu praksu, ne zaboravljajući pritom cjelinu konteksta poslanja Crkve kao takve. Takav nam se pristup posebno nameće zato što u ovakvom radu zasigurno nije moguće detaljno obraditi sva pitanja koja se u odnosu na pastoral braka i obitelji u tom dokumentu ističu, ali

\footnotetext{
${ }^{1}$ Usp. PAPA FRANJO, Amoris laetitia - Radost ljubavi. Posinodalna apostolska pobudnica biskupima, prezbiterima i đakonima, posvećenim osobama, kršćanskim supruzima i svim vjernicima laicima o ljubavi u obitelji, Zagreb, 2016., br. 7 (= AL). Autor je na sličan način zadanu tematiku obradio i u knjizi: N. VRANJEŠ, Za novi život u Kristu. Prilozi pastoralu sakramenata, Zagreb, 2017., 144.-176.
} 
i zato što takav pristup nudi dovoljno mogućnosti kako bismo tematiku prikazali na što je moguće aktualniji način.

\section{Elementi i etape pastorala braka i obitelji}

Papa Franjo u toj pobudnici glavnim elementima i etapama pastorala braka i obitelji pristupa određenim pastoralnim sažimanjem tematike, a u isto vrijeme vrlo je aktualan i precizan u određivanju ključnih točaka današnjih izazova, ali i perspektiva u tom području pastorala. Polazi od tvrdnje da su glavni nositelji pastorala braka i obitelji same kršćanske obitelji u snazi sakramenta ženidbe i svjedočanstva njihova života. ${ }^{2}$ Obitelj, kao Crkva u malom, temeljna je okosnica života, a samim time i Crkve. Obitelj ima nezamjenjivo mjesto u Crkvi, dok je Crkva s druge strane nezamjenjiv kršćanski duhovno-sakramentalni i odgojno-katehetski okvir za same obitelji. Obitelj i Crkva predstavljaju međusobno isprepletene stvarnosti, određene i upućene jedna na drugu. U odnosu na pastoral braka i obitelji to konkretno znači da je Crkva, u određenom smislu, pratiteljica i pomoćnica u svim etapama i s obzirom na sve elemente obiteljskoga života.

Elementi i etape pastorala braka i obitelji u tome su dokumentu jasno određeni, ali i prikazani međusobno upućeni i isprepleteni. Tako se element priprave promatra kroz njezine etape, dok neke druge poput teme odgoja, komunikacije, duhovnosti, suradnje, pastoralnoga praćenja i podrške, suočavanja s kriznim situacijama i ostale možemo uočiti kao prilično jasno izdvojene.

Etape djelovanja jasno su određene i logično posložene, pri čemu na poseban način valja uočiti Papinu nakanu preciznoga određivanja nosivih sastavnica problematike braka i obitelji u pojedinim etapama života. Očita je pritom nakana izdvajanja pitanja koja su u današnjem pastoralnom i društvenom kontekstu najaktualnija.

\subsection{Priprava Za brak}

Procesu priprave za brak i u tom se dokumentu pristupa kao složenoj stvarnosti koja se ostvaruje tijekom triju temeljnih etapa, tj. dalje, bliže i neposredne priprave. Papa Franjo tu pripravu vidi u prvome redu u svjetlu rasta i sazrijevanja za život odgovorne ljubavi u čemu budućim supruzima trebaju pomoći važni društveni i crkveni čimbenici. Upravo je taj rast jedan od ključnih izraza u cijelome tome dokumentu, a u odnosu na pripravu za brak posebno je naglašen.

Dalja priprava za ženidbu uključuje dugo razdoblje od djetinjstva, tj. počevši od roditeljskoga doma pa tijekom uključenosti u crkvene, školske, studentske, kulturne i druge dinamike sve do vremena zaručništva i bliže priprave za ženidbu. To

${ }^{2}$ Usp. isto, br. 200. 
dugo razdoblje u vjerskom pogledu nužno je danas bolje iskoristiti. Obitelj iz koje budući zaručnici dolaze u tome je pogledu osobito važan čimbenik. Ona bi trebala biti prva škola ljubavi i zajedništva. Njezin život molitve, uključenost u dinamiku župne zajednice, osobito u katehezu i sakramentalna slavlja, gajenje određenih oblika pučke pobožnosti i druge aktivnosti djeci i mladima na prilagođen će način ponuditi mnoge važne uvide s obzirom na obiteljski život iz kršćanske perspektive.

Cjelokupna priprava za ženidbu, a osobito ona bliža, u tome se dokumentu sagledava vrlo realno; moglo bi se čak reći možda i malo realnije od uobičajenih načina na koje smo se naviknuli u Crkvi kada je riječ o tim temama. Naime, papa Franjo pripravu za brak vidi u prvome redu u svjetlu donošenja istinskih i trajnih odluka za cjeloživotni zajednički poziv u braku, tj. u svjetlu slobodnoga i odgovornoga preuzimanja obveza te u svjetlu odlučnosti i opredijeljenosti za potpunu predanost drugoj osobi. U tome je pogledu vrlo jasan $\mathrm{s}$ obzirom na problem ulaženja u bračnu zajednicu samo na temelju privremene zaljubljenosti i emocionalne očaranosti drugom osobom, što danas predstavlja velik problem. Stoga i ističe da takve stvarnosti nipošto ne mogu jamčiti budući zajednički život i da je važno da zaručnici to jasno uvide prije sklapanja ženidbe. ${ }^{3}$

Poseban naglasak u pripravi za ženidbu i u pastoralu zaručništva nužno je staviti na odgoj za krjeposti, osobito za čistoću, ali i za tolike druge krjeposti i vrline koje će zaručnicima, $\mathrm{tj}$. budućim supruzima, pomoći živjeti i sazrijevati zajedno. $\mathrm{U}$ tome pogledu osobito se ističe važnost pouke zaručnika u smislu da ženidbeno slavlje ne shvate kao završetak nekoga puta, već kao početak jednoga novoga hoda koji s obzirom na sazrijevanje u ljubavi i zajedništvu traje cijeli život.

Neposredna priprava za ženidbu, u kojoj uz zaručnike odlučujuću ulogu imaju župnik i župna zajednica, trebala bi se shvatiti kao svojevrsna rekapitulacija cijeloga puta priprave i u duhovnom i u pastoralnom pogledu. Uz nužne kanonske pretpostavke, koje tada trebaju biti definitivno određene i potvrđene, osobito je važno zaručnike na primjeren način pripremiti za slavlje i uvesti ih u njegovu simboliku. Taj je naglasak tim važniji ako se u obzir uzme izuzetno velika vjerska nepoučenost tolikih zaručnika kojima je razdoblje priprave za ženidbu možda i jedina duža prigoda za dublju katehezu, ne samo o ženidbi već i općenito o kršćanskom životu, ali i o liturgiji. ${ }^{4}$ Nužno bi stoga bilo na prilagođeni im način što istinskije približiti liturgiju ženidbe, a preko nje i druge segmente kršćanskoga bogoslužja.

\footnotetext{
${ }^{3}$ Što jasno proizlazi iz Papinih riječi. Usp. isto, br. 209.

${ }^{4}$ Usp. isto, br. 213.
} 


\subsection{PosLIJEŽENIDBENI PASTORAL: PRAĆENJE I PODRŠKA}

U skladu s prethodnim razmišljanjima o pripravi za ženidbu u pobudnici Amoris laetitia papa Franjo govori o potrebi posliježenidbenoga pastorala i to počevši od samoga slavlja vjenčanja. Prve godine zajedničkoga života osobito su izazovne za većinu bračnih parova i obitelji. To se većinom događa zbog popuštanja zaljubljenosti, krhkosti osoba, ${ }^{5}$ kasnijega sazrijevanja mladih u današnjoj kulturi, kao i zbog niza drugih čimbenika koji proces priprave i zaručništva čine parcijalnim, pa mnogi bračni parovi u prvim godinama braka zapravo moraju nadoknaditi ono što nije učinjeno prije u smislu odgoja i kateheze. Zato je osobito važno razvijati dinamiku pastoralnoga praćenja osoba, posebno u prvim godinama braka. To pastoralno praćenje osoba, koje u nauku pape Franje predstavlja jednu od ključnih postavki ukupne pastoralne dinamike Crkve, ${ }^{6}$ u području pastorala braka i obitelji poprima sasvim posebno značenje. ${ }^{7}$ Nužno ga je ponajprije shvaćati i aktualizirati u ukupnom sazrijevanju mladih u ljubavi, kroz prizmu koje treba sagledavati ženidbu. Papa ističe da $\gg$ moramo držati velikom vrjednotom da se ženidba shvaća kao pitanje ljubavi, da se mogu ženiti samo oni koji slobodno izaberu jedno drugo i koji se vole $\ll^{8}$ No ta ljubav ne smije ostati tek na razini zaljubljenosti ili fizičke privlačnosti, već ju nužno treba sagledavati u smislu cjeloživotnoga sazrijevanja. Ženidbu stoga treba promatrati i kao zajednički životni projekt izgrađivanja zdravoga i zreloga odnosa. Zato je osobito važno u prvim godinama braka bračnim partnerima pomoći shvatiti i živjeti ljubav kao stvarnost u pokretu, kao nešto što raste i napreduje. ${ }^{9}$ Vježbanje u uzajamnoj ljubavi ${ }^{10}$ zato je presudno osobito u tim prvim godinama braka.

\footnotetext{
${ }^{5}$ U pobudnici Evangelii gaudium Papa upozorava da je upravo opća krhkost vezâ danas postala posebno opasna za brak i obitelj. Usp. PAPA FRANJO, Evangelii gaudium - Radost evandelja. Apostolska pobudnica biskupima, prezbiterima i dakonima, posvećenim osobama i svim vjernicima laicima o navještanju evandelja u današnjem svijetu, Zagreb, 2013., br. 66 (= EG).

${ }^{6} \mathrm{O}$ njemu papa Franjo na poseban način govori u apostolskoj pobudnici Evangelii gaudium. Usp. isto, br. 169. Usp. P. G. ACCORNERO, »La gioia dell'amore «: la nuova costituzione per la famiglia, u: Orientamenti pastorali 64(2016.)9, 24.

${ }^{7}$ U tome pogledu papa Franjo poziva se i na Ivana Pavla II (usp. AL, br. 223) koji je također jasno istaknuo potrebu takvoga pristupa u pastoralu braka i obitelji. Usp. IVAN PAVAO II, Obiteljska zajednica - Familiaris consortio. Apostolska pobudnica o zadaćama kršćanske obitelji u suvremenom svijetu, Zagreb, ${ }^{2}$ 1997., br. 33, 49.-84.
}

${ }^{8}$ AL, br. 217.

${ }^{9}$ Upravo je to jedna od glavnih oznaka viđenja ljubavi u teologiji pape Franje. Usp. G. ALCAMO, Accoglienza, accompagnamento, discernimento, in una nuova prospettiva di fiducia e di speranza, u: Orientamenti pastorali 64(2016.)9, 26.-27.

${ }^{10} \mathrm{AL}$, br. 220. 
Koliko je tema shvaćanja braka i bračne ljubavi kroz prizmu sazrijevanja, rasta i napretka važna u misli pape Franje, govori i činjenica da on upravo manjak takvoga shvaćanja braka kod supružnika vidi kao jedan od važnih uzročnika brzopletoga i neodgovornoga pomišljanja na rastavu kada se u braku pojave određeni problemi. ${ }^{11}$ Drugim riječima, kada se od bračnoga života očekuje savršenstvo, tj. kada su očekivanja nerealno i neopravdano visoka, a k tomu se ne shvaća da je brak put sazrijevanja koji ima svoje etape i svoju logiku podložnu nesavršenosti, onda redovito dolazi do nerazumijevanja i lomova. Rješenje nije rastava ni pretvaranje zajedničkoga života tek u zajedljivi suživot ispunjen gorčinom, neprestanim međusobnim propitivanjem, optuživanjem i kritizerstvom. Put obnove jest u procesu sazrijevanja u ljubavi kao umijeću koje pomaže drugu osobu uvijek prepoznavati u njezinu dostojanstvu, gledati je kroz prizmu dobra i pomagati joj na putu oblikovanja vlastitoga identiteta.

$S$ obzirom na pastoralno praćenje i podršku crkvene zajednice mladim bračnim parovima možemo izdvojiti još dva upečatljiva elementa koja Papa ističe u toj pobudnici, a koji su jedan više duhovno-egzistencijalne, a drugi više pastoralno-metodološke naravi. Prvi element tiče se zajedničkoga kvalitetnoga provođenja vremena. Možemo istaknuti da je nekvalitetno provođenje vremena danas postalo pravi teret tolikim našim suvremenicima, ali i tolikim kršćanima. U određenom se smislu može reći da je to teret i u tolikim crkvenim zajednicama. Također se u nekom pogledu može reći da je to neizostavna napast koju u određenom smislu svaki čovjek mora iskusiti i boriti se s njom. Papa taj problem ovdje posebno evocira u odnosu na bračne parove i to osobito mlade koji su netom ili tek prije nekoga kraćega vremena proslavili vjenčanje. ${ }^{12}$ Problem nekvalitetnoga zajedničkoga provođenja vremena u tom razdoblju javlja se gotovo redovito, stoga je parovima nužno pomoći kako bi pronalazili i aktualizirali domišljate nove načine uvijek ponovnoga ispunjavanja zajedničkih trenutaka smislom i ljubavlju. $U$ tome pogledu osobito je važno umijeće uživanja u radosti zajedničkih obiteljskih rituala, obljetnica i posebnih događaja koji uvijek iznova unose novu svježinu u život.

Drugi od gore spomenutih elemenata više pastoralno-metodološke naravi tiče se načina djelovanja župa i drugih kršćanskih zajednica u pastoralu braka i obitelji, načina koji treba biti bitno misionarski, a manje usredotočen na puku organizaciju aktivnosti, koja prečesto postaje čisti aktivizam. U tome pogledu Papa osobito upozorava na potrebu da današnji pastoral braka i obitelji treba osloboditi bremena pretvaranja u tzv. »tvornicu tečajeva « koji su većinom slabo posjećeni. ${ }^{13}$ Potrebno

\footnotetext{
${ }^{11}$ Usp. isto, br. 221.

${ }^{12}$ Usp. isto, br. 224-225.

${ }^{13}$ Usp. isto, br. 230.
} 
ga je, naprotiv, više usmjeriti prema izlasku ${ }^{14}$ među ljude, među obitelji, u društvo, prema kulturnim događanjima kako bi se u otvorenoj misionarskoj dinamici mogla ponuditi kršćanska vizija života, a s druge strane kako bi sam taj pastoral mogao biti oplemenjen novim suvremenim uvidima. ${ }^{15} \mathrm{Na}$ taj način može se postići nova razina pastoralne aktualizacije i sinteze.

\subsection{U KRIZNIM I TEŠKIM OKOLNOSTIMA}

Pastoral braka i obitelji ne može se svesti samo na dinamiku redovitoga praćenja, osobito mladih bračnih parova, već treba nužno biti otvoren i za dimenziju kriznih, problematičnih, neredovitih i neregularnih situacija s kojima će se pastoralni djelatnici susresti prije ili kasnije. Papa stoga upravo tim temama pridaje veliku važnost i to u sklopu govora o cjelovitom pastoralnom nastojanju s obzirom na bračnu i obiteljsku tematiku. I te teme, koje su po sebi vrlo različite, a opet u određenom smislu i vrlo povezane, Papa sagledava u logici sazrijevanja i napredovanja u ljubavi. Pritom je važno razumjeti da su osobne situacije i situacije pojedinih bračnih parova različite i da pogotovo treba razlikovati situacije kriza i izazova koje će sigurno doći od situacija tzv. neregularnosti ili neredovitosti koje, po sebi, također podrazumijevaju određene krize, ali koje s obzirom na pastoral Crkve predstavljaju drukčiji okvir angažmana.

Ako u sklopu naznačene logike promišljanja pođemo od pitanja kriza u braku i obitelji, važno je ponajprije uočiti znakovitost podnaslova kojim započinje ulomak šestoga poglavlja pobudnice o toj temi, a koji glasi: Unositi svjetlo u krize, tjeskobe i teškoće. ${ }^{16}$ Ta znakovitost čini nam se osobito važnom jer očito odražava Papinu nakanu da djelovanje Crkve u odnosu na problematiku kriza u braku i obitelji sagleda i predoči kroz prizmu pomoći koju Kristova zajednica treba ponuditi obiteljima donoseći im svjetlo i snagu evanđelja. Crkva je pozvana pomoći obiteljima osvijetliti njihovu obiteljsku stvarnost, ma kakva ona bila, svjetlom Kristove nazočnosti koje uvijek nudi pogled na nove horizonte života i pomaže prebroditi izazove. Krize su sastavni dio bračne i obiteljske stvarnosti. One također odražavaju nešto njezine

\footnotetext{
${ }^{14}$ Treba pritom podsjetiti na činjenicu da je pastoralni misionarski izlazak Crkve u suvremeno društvo, a osobito na njegove egzistencijalne periferije jedna od najvažnijih poruka pontifikata pape Franje. Više o tome vidi u: N. VRANJEŠ, Crkva koja izlazi. Aktualnost apostolske pobudnice Evangelii gaudium pape Franje, u: Diacovensia 22(2014.)4, 448.-449.

${ }^{15}$ Upravo zahtjev za više takvog pastoralnoga pristupa, koji odzvanja u cijeloj poruci pape Franje, možemo izdvojiti kao jednu od važnih točaka unaprjeđenja ukupnoga pastorala i u našim hrvatskim prilikama. Više o tome vidi u: B. MURIĆ, Narod Božji kao nositelj navještaja Crkve. Evangelii gaudium i misionarska preobrazba Crkve, u: Diacovensia 22(2014.)4, 472.-480., 488.-491.

${ }^{16}$ Usp. AL, br. 231.
} 
dramatične ljepote. ${ }^{17}$ Stoga su bračni parovi i obitelji pozvani na krize ne gledati kao na nepremostive prepreke, već kao na prilike za sazrijevanje na nov način u logici pročišćenja i poboljšanja. Crkva im treba pomoći kako bi uvidjeli mogućnosti takvoga pristupa i odvažili se krenuti takvim putem, tj. kako ne bi upadali u zamku razočaranja koja povlači prema zamiranju odnosa ili pak trpljenju životne osrednjosti. $^{18}$

\subsubsection{Komunikacija u braku i obitelji}

U okviru govora o problemu kriza i izazova u braku i obitelji Papa se zaustavlja na jednoj od tema koje čine okosnicu obiteljskoga života, ali i cjelovitoga nastojanja oko skrbi za brak i obitelj, a riječ je o temi komunikacije u braku i obitelji. Komunikacija je stožerna sposobnost koja čovjeku kao biću odnosa omogućuje ostvarivanje istinskoga ljudskoga života u zajedništvu s drugim ljudima. Brak i obitelj, kao temeljni oblici zajedništva, predstavljaju stoga ambijente u kojima bi ljudska osoba trebala na osobito pozoran i dosljedan način živjeti istinsku komunikaciju.

Obiteljski ljudi svjedoče da je jedan od najvećih neprijatelja braka ubojita tišina, tj. tišina koja ubija. ${ }^{19}$ Postoje i oblici dobre, kreativne tišine koji su potrebni svakom ljudskom biću, a koji su potrebni i u braku i obitelji. No tišina koja je posljedica udaljavanja od bračnoga partnera ili pak nerazumijevanja, neslaganja i manjka dijaloga s vremenom postaje vrlo opasna. Takva tišina može nastati i uslijed kriza i izazova, na koje odgovor može biti i nerješavanje problema ili pak njihovo nijekanje, na što se u toj pobudnici posebno upozorava. Među prvim posljedicama takvoga pristupa jest ugrožavanje komunikacije. ${ }^{20}$ Daljnja je posljedica toga udaljavanje od druge osobe, što na dužu stazu vodi zamiranju odnosa. Dodatni problem može predstavljati povlačenje u sebe, u tzv. kukavičku i prijevarnu šutnju, što je najčešće posljedica manjka spremnosti ili uopće umijeća istinske komunikacije od srca k srcu. ${ }^{21}$ Čini se da mnogi supruzi uđu u bračnu zajednicu na temelju tek djelomičnoga

${ }^{17}$ Usp. isto, br. 232.

${ }^{18}$ Isto, br. 232: »Ni u kojem se slučaju ne smije miriti s time da su stvari krenule silaznom stazom, s neizbježnim pogoršavanjem odnosa ili trpljenjem osrednjosti. Naprotiv, kada se na brak gleda kao na izazov, koji također uključuje prevladavanje zapreka, svaka kriza doživljava se kao prigoda da se stigne do trenutka kada se zajedno pije najbolje vino. Dobro je pomagati bračnim drugovima kako bi se mogli suočiti s krizama koje mogu doći, prihvatiti ih kao izazov i priznati ih dijelom obiteljskog života.«

${ }^{19}$ Kao što je to jasno izrečeno u jednom djelu o nekim drugim pastoralno-duhovnim temama u kojem se tvrdi da su mnogi brakovi umrli upravo zbog takve tišine. Usp. J. FOREST, The Road to Emmaus. Pilgrimage as a Way of Life, Maryknoll, 2007., 27.

${ }^{20}$ Usp. AL, br. 233.

${ }^{21}$ Usp. isto, br. 234. 
poznavanja druge osobe i bez jasne sposobnosti za istinsku komunikaciju. U vrijeme zaručništva, dok naglasak stavljaju uglavnom na zaljubljenost, to ne predstavlja velik problem. No problem se velikim redovito pokaže kasnije u braku.

Jedan od dodatnih problema s obzirom na pastoral Crkve predstavlja nedovoljno razumijevanje, a mogli bismo općenito reći i sposobnost i kompetentnost u procesima savjetovanja osoba, zbog čega mnoge više ni ne traže pomoć Crkve. Papa zato upozorava da $\gg$ odgovori s provedenih savjetovanja pokazuju da većina ljudi u teškim i kritičnim situacijama ne traži pastoralnu pomoć, jer ju ne doživljava kao nešto što odiše razumijevanjem, bliskošću, osjećajem za stvarnost ili sposobnošću da se dublje uđe u problem. To bi nas trebalo potaknuti da bračnim krizama pokušamo pristupati s većom osjetljivošću za njihov teret boli i tjeskobe $\ll^{22}$

Angažman samih bračnih partnera i obitelji, ali i pastoralni doprinos Crkve u odnosu na napredak i rast u zrelosti komunikacije, nužno je ostvarivati u logici pomirenja i oslobođenja. Ta dva procesa, pomirenje i oslobođenje, nikako se ne smije promatrati tek kao opcionalne dinamizme, već nužno kao sigurne sastavnice ljudskoga i kršćanskoga života u čiju dinamiku treba biti uključena svaka osoba koja želi napredovati na putu zrelosti. Papa Franjo, ponavljajući neke zaključke Relatio Synodi iz 2014. godine, ističe da je oproštenje temeljno iskustvo obiteljskoga života te da je pomirenje ponekad i vrlo teško iskustvo koje zahtijeva i pomoć drugih čimbenika. ${ }^{23}$

Osobitu teškoću u dinamici pomirenja i zrele komunikacije može predstavljati emocionalna nezrelost koja se vrlo često očituje u pridavanju prevelike emocionalne pozornosti situacijama koje to ne zaslužuju. Kako bi bračna i obiteljska komunikacija napredovala i nju je potrebno sagledavati kroz prizmu rasta u zrelosti. Papa stoga, nudeći drukčiju perspektivu od one kojoj mnogi redovito teže, progovara o primjeru osoba koje unatoč težini okolnosti kriza svjedoče potrebnu zrelost koja jedina vodi poboljšanju odnosa i sazrijevanju: »U takvim okolnostima, neki imaju potrebnu zrelost da potvrde svoje opredjeljenje za drugoga kao životnog suputnika, bez obzira na ograničenja odnosa, i realno prihvaćaju da drugi ne može ispuniti sve njihove lijepe snove koje su sanjali. Takve osobe izbjegavaju držati se jedinim mučenicima, cijene male i ograničene mogućnosti što ih pruža obiteljski život i rade strpljivo i polako na jačanju bračne veze. One su stekle duboku svijest o tome da svaka kriza može biti novi 'da' koji omogućuje da ljubav iz nje iziđe ojačana, promijenjena, zrelija i iznutra učvršćena. Kad kriza prođe, imaju hrabrosti tražiti duboke korijene onoga što se događa, ponovno pregovarati o temeljnim stvarima,

\footnotetext{
${ }^{22}$ Isto.

${ }^{23}$ Usp. isto, br. 236.
} 
naći novu ravnotežu i zajedno otpočeti novu etapu. S tim stajalištem stalne otvorenosti mogu se suočiti s mnogim teškim situacijama! $\ll^{24}$

Komunikacija u braku i obitelji usko je povezana sa shvaćanjem i življenjem ljubavi koju, kako smo već zamijetili, Papa shvaća ključnim čimbenikom bračnoga i obiteljskoga života. Upravo nezrelost u dimenziji ljubavi u svojim različitim očitovanjima može bitno narušiti i ugroziti komunikaciju. Papa u tome pogledu osobito ističe problem hirovite, egocentrične, nezasitne, buntovničke, kritizerske ili pak ljubavi obuzete vlastitim emocijama i maštama, tj. oblika ljubavi koji, svaki na svoj način, samo predstavljaju naličje emocionalne nezrelosti. ${ }^{25}$ Takvi oblici ljubavi često su povezani i s ožiljcima od starih životnih rana koji redovito samo predstavljaju izlike i poticaje za produbljivanje sukoba, osobito ako su te rane povezane s neriješenim sukobima i lomovima u prošlosti, koji poput vrhova zaleđenih santi u duhovnom i psihološkom prostoru osobe izviruju i redovito ostavljaju pogubne posljedice u području komunikacije.

U tome pogledu istinski lijek i jedini pravi put napredovanja u bezuvjetnoj ljubavi, a time i u istinskoj komunikaciji s drugima, jest pomirenje koje vodi k oslobođenju. Dinamizmi pomirenja i proces oslobođenja, koji uključuje i unutarnje ozdravljenje od starih rana, zahtijevaju hrabrost i odlučnost, a u prvome redu iskrenost. Upravo su to bitni elementi bračne i obiteljske komunikacije. Papa u tome pogledu osobito ističe važnost suočavanja s vlastitom prošlošću i dodaje: $\gg$ To podrazumijeva prepoznavanje potrebe za ozdravljenjem, ustrajnu molitvu za milost davanja i primanja oproštenja, spremnost prihvatiti pomoć i odlučnost da se ne odustane, nego da se i dalje pokušava. Svatko mora biti iskren prema sebi kako bi spoznao da njegov način življenja ljubavi izražava nezrelost. Čak i ako je jasno da je krivnja na drugome, kriza se nikada neće prevladati jednostavno čekajući da se samo drugi promijeni. Potrebno je preispitati se o tome što je to što u našem vlastitom životu treba rasti ili ozdraviti kako bi se sukob riješio. $\ll{ }^{26}$

\subsection{U NEREDOVITIM I NEREGULARNIM OKOLNOSTIMA}

Situacije toga tipa na poseban su način obrađene u osmome poglavlju te pobudnice naslovljenom Pratiti, razlučivati $i$ integrirati slabosti. Važno je primijetiti da ih Papa naziva takozvanim $\gg$ neredovitim $\ll$ situacijama. ${ }^{27}$ Komentatori, a osobito bečki kardinal Christoph Schönborn, ističu da se time željelo istaknuti prvotno dostojanstvo

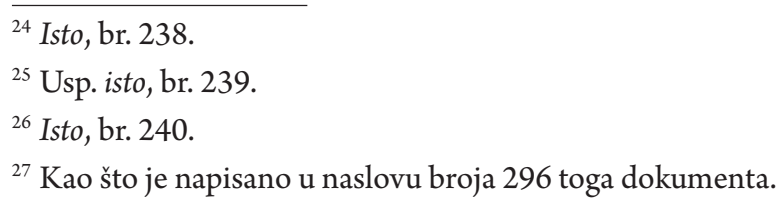


i jednakost svih pred Bogom, a da se tek potom može govoriti o različitosti prilika u kojima pojedini vjernici žive. ${ }^{28} \mathrm{U}$ šestom poglavlju pobudnice o tim se pitanjima posebno progovara od 241. do 246. broja. U svim tim dijelovima jasno je, ponajprije, uočljivo Papino mišljenje da su ta pitanja vezana za neke od najtežih okvira pastoralnoga djelovanja s obzirom na brak i obitelj. On ih u tom dokumentu nastoji sagledati razlučivanjem problematike koja može imati različite uzročnike i uključivati različite razine odgovornosti osoba uključenih u nju. Tako u 241. broju te pobudnice polazi najprije od situacija u kojima je rastava (očito ona od stola i postelje) nužna pa sve do onih koji su se civilno razveli, do onih koji su kao takvi stupili u novu vezu ili u novi civilni brak. Odgovornost subjekata takvih situacija može se promatrati od one koja uključuje pun i namjeran nemar i svjesno razaranje veze do manjih oblika ili pak slučajeva osoba koje rastavu nisu htjele, ali su nepravedno napuštene ili su pak s vremenom postale žrtve nasilja supružnika i sl. Ne ulazeći u moraliziranje ni detaljniju obradu uzročnika u tom segmentu problematike Papa usmjeruje pozornost Crkve prema pastoralu pomirenja, posredovanja i praćenja. ${ }^{29}$ Osobita je odgovornost Crkve danas u tome pogledu nuditi pomoć osobama prikladnim sredstvima i ustanovama, od kojih se posebno ističu prihvatilišni centri za osobe kojima je potrebna pomoć u naznačenim situacijama, a koje treba osnovati u biskupijama. ${ }^{30}$

Posebno su pastoralno izazovne situacije osoba koje su stupile u novu vezu ili novi civilni brak. Papa u tome pogledu izražava suvremeni stav Crkve prenoseći riječi sinodskih otaca: $\gg$ Te situacije zahtijevaju pomno razlučivanje i praćenje ispunjeno poštovanjem, izbjegavajući svaki govor i stajalište zbog kojega će se oni osjetiti izopćenima i promičući njihovo sudjelovanje u životu zajednice. Briga koja se posvećuje tim osobama ne slabi vjeru zajednice i njezino svjedočanstvo o nerazrješivosti ženidbe, nego, štoviše, ona upravo po toj brizi izražava svoju ljubav. ${ }^{31}$ Osobita pozornost crkvene zajednice treba biti usmjerena prema djeci, tj. prema odgoju novih naraštaja također onih roditelja koji su ušli u novi građanski brak. To treba biti dodatan motiv da se takve parove ne smatra izopćenima, već da se i njima pruži pomoć u skrbi za odgoj djece. ${ }^{32} \mathrm{~S}$ obzirom na pitanje pripuštanja sakramentima

\footnotetext{
${ }^{28}$ Navedeno prema: P. G. ACCORNERO, »La gioia dell'amore «: la nuova costituzione per la famiglia, 23.-24.

${ }^{29}$ Usp. AL, br. 242-243.

${ }^{30}$ Usp. isto, br. 242.

${ }^{31}$ Isto, br. 243.

${ }^{32}$ To bi trebalo tim više smatrati važnim jer, prema istraživanjima, i u našoj domovini odnos prema ulozi roditelja u odgoju i odrastanju djece postaje sve problematičniji, tj. po određenim se pokazateljima tom odnosu sve manje pridaje važnost. Usp. J. BALOBAN, K. NIKODEM, D. CRNIĆ, Analiza stavova o braku i obitelji u Hrvatskoj i u Europi, u: J. BALOBAN - K. NIKODEM - S. ZRINŠČAK, (ur.), Vrednote u Hrvatskoj i u Europi. Komparativna analiza, Zagreb, 2014., 107.
} 
razvedenih i ponovno civilno vjenčanih treba istaknuti (ali bez namjere dubljega ulaženja u problematiku u ovom radu) da bi ipak bilo preširoko tumačenje Papinih riječi koje bi išlo neposredno za odobravanjem takve prakse jer Papa govori o važnosti razlučivanja pojedinih situacija, ali u duhu i kontekstu dosadašnjega nauka i discipline Crkve, na što posebno trebaju paziti svećenici. ${ }^{33}$ Također u duhu cjelovitoga sagledavanja Papina nauka valja dodati njegovo isticanje da je razvod zlo s kojim se treba suočavati, na koje treba upozoravati i koje treba prevenirati. Crkva je u tome pogledu pozvana uvijek se vraćati najvažnijoj pastoralnoj zadaći u tom smislu, a to je ojačavanje ljubavi i zacjeljivanje rana. ${ }^{34}$

\subsection{BRAK U STAROSTI I PRIPRAVA ZA SMRT}

Pastoral braka i obitelji, kao i ukupno pastoralno djelovanje Crkve, označen je nastojanjem pomoći i podrške u svim fazama života, pa tako i u posljednjoj. Upravo ona, a osobito ako je označena bolešću, nemoći ili udovištvom, može predstavljati poseban izazov. U toj pobudnici izazovi toga tipa u završnom su dijelu šestoga poglavlja pod određenim vidom sažeti u smislu razmišljanja o suočavanju s posljednjom ovozemaljskom stvarnošću, tj. s pripravom za smrt i s umiranjem. Papa Franjo u tome pogledu jezgrovito poučava o temeljnim elementima kršćanskoga suočavanja sa smrću i tugovanjem nakon smrti voljene osobe.

S obzirom na to pitanje promišljanja su na poseban način usmjerena osvjetljavanju nekih od ključnih razloga problema u odnosu na te teme. Jedan je od njih prihvaćanje dinamike tugovanja, s kojim i mnogi kršćani imaju velikih problema. Stoga se ističe da je tugovanje u načelu dug ili duži proces koji ima određene faze i koji je nužno proživjeti i to kroz ustrajni hod molitve i unutarnjega oslobođenja. ${ }^{35}$ Takav hod omogućuje preusmjeravanje pogleda s horizonta prošlosti na obzor nadolazeće eshatološke stvarnosti, a upravo to preusmjeravanje mnogima predstavlja problem jer se nakon smrti drage osobe obično vraćaju na prošlost. Kršćanska perspektiva nikako ne smije biti zadržavanje u takvom stanju i iscrpljivanje u patnji. Pastoralna pozornost Crkve osobama tada treba pomoći upravo u naznačenom preusmjeravanju pogleda i nastavljanju životne misije. Mnogi upravo u tim trenutcima ostaju blokirani, a život im postaje više životarenje nego istinsko življenje. Papa stoga upozorava: »U određenom trenutku tugovanja osobi koja tuguje moramo pomoći shvatiti da, nakon gubitka voljene osobe, još uvijek pred sobom ima misiju koju treba ispuniti, te da nije dobro produljivati patnju, kao da je riječ o svojevrsnom odavanju počasti. Voljena osoba ne treba našu patnju, niti joj laska što uništavamo svoje živote. Najbolji izraz ljubavi

\footnotetext{
${ }^{33} \mathrm{U}$ tome pogledu treba osobito pozorno i cjelovito iščitati br. 300 toga dokumenta.

${ }^{34}$ Usp. AL, br. 246.

${ }^{35}$ Usp. isto, br. 255.
} 
također nije sjećati se i spominjati ju u svakom trenutku, jer to znači ostati privezan uz prošlost koje više nema, umjesto da se ljubi stvarnu osobu koja se sada nalazi na drugome svijetu. Ona više ne može biti fizički nazočna, ali, premda je smrt moćna, 'ljubav je jaka kao smrt' (Pj 8,6). Ljubav posjeduje intuiciju koja joj pomaže osluhnuti nečujno i vidjeti nevidljivo. To ne znači zamišljati dragu osobu kakva je bila, nego moći ju prihvatiti preobraženu, kakva je sada. $\ll^{36}$

Papa se u pogledu suočavanja s pitanjem smrti ponovno vraća na temeljnu nakanu toga dokumenta, a riječ je o pastoralnom pridonošenju rastu osoba u ljubavi i napredovanju na putu zrelosti. $U$ toj perspektivi potrebno je sagledavati i pitanje smrti. Upravo u toj perspektivi postaje jasno da je nužno prihvatiti smrt i pripravljati se za nju. Najbolji put takvoga pripravljanja nije neprestano vraćanje u prošlost, već aktualno, svakodnevno življenje ljubavi prema onima koji su nam na tom putu povjereni. U tome smislu Papa poziva: »ne rasipajmo snage razmišljajući u nedogled o dalekoj prošlosti. Što bolje živimo na ovoj zemlji, to ćemo veću sreću moći dijeliti s našim voljenima na nebu. Što više uspijemo sazreti i rasti na ovome svijetu, to ćemo više lijepih stvari donijeti na nebesku gozbu. ${ }^{37}$

\section{Perspektive razvitka i unaprjeđenja pastorala braka i obitelji}

Naširoko se koristeći zaključcima XIV. opće redovite skupštine Biskupske sinode u Rimu, tzv. Relatio finalis, papa Franjo u odnosu na temu perspektiva razvitka s obzirom na temeljne elemente pastorala braka i obitelji najprije polazi od ćinjenice da je danas nužno dublje pastoralno ulaženje Crkve u problematiku suvremenih obiteljskih situacija s nakanom pomoći i spasenjskoga zauzimanja. To znači da su pastoralni djelatnici pozvani ostati vjerni učenju Crkve, ali nikada ne ostajući u svome pastoralnom zalaganju na razini teorijskih razlaganja. Nužno je danas odlučnije se suočavati s dramatičnošću različitih obiteljskih prilika u prvome redu predlažući evanđelje obitelji kroz vrjednote i ljepotu poziva koji predstavlja odgovor na najdublja očekivanja života. ${ }^{38}$

Kako bi to bilo moguće crkvene će zajednice morati poraditi na metodologiji svoga djelovanja. Razvijanje novih pastoralnih metoda te osmišljavanje praktičnijih i učinkovitijih prijedloga pastoralnoga djelovanja predstavlja drugu važnu perspektivu razvitka pastorala braka i obitelji. ${ }^{39}$ Može se reći da u tome smislu papa Franjo i u tom dokumentu iznova potiče Crkvu na premišljanje načina svoga djelovanja

\footnotetext{
${ }^{36}$ Isto.

${ }^{37}$ Isto, br. 258.

${ }^{38}$ Usp. isto, br. 201.

${ }^{39}$ Usp. isto, br. 199.
} 
te na nov pomak u odgovornoj pastoralnoj inovativnosti i kreativnosti na koje je posebice pozvao u pobudnici Evangelii gaudium. ${ }^{40}$ Pritom je važno uočiti da je to pitanje jedno od najaktualnijih i u odnosu na našu pastoralu praksu. ${ }^{41}$

Važnu perspektivu razvitka pastorala braka i obitelji, koju papa Franjo u naznačenom području našega istraživanja posebno ističe, možemo prepoznati i u potrebi prikladnijega i snažnijega zauzimanja stručnih vjernika laika u tome pastoralnome području, ${ }^{42}$ a s druge strane i u osnaživanju cjelovitijega i boljega formiranja svećenika, osobito s obzirom na interdisciplinarnu suradnju teologije i društvenih i humanističkih znanosti te korištenja njihovih dosega u pastoralu. ${ }^{43}$ Drugim riječima, pastoral braka i obitelji u svim njegovim segmentima treba osnažiti i unaprijediti pod vidom kompetentnosti i profesionalnosti njegovih subjekata.

\section{Bračna i obiteljska duhovnost}

Progovarajući o bračnoj i obiteljskoj duhovnosti kao posebnoj temi završnoga, devetoga poglavlja pobudnice, papa Franjo jasno potvrđuje učenje Drugoga vatikanskoga koncila koje kršćansku duhovnost drži jedinstvenom stvarnošću koja ipak poprima različite konture ovisno o pozivu i načinu života na koji je pojedini vjernik u Crkvi i u svijetu pozvan. ${ }^{44} \mathrm{~S}$ obzirom na bračnu i obiteljsku duhovnost to znači da je jedna od njezinih temeljnih odrednica i, zapravo, jedno od njezinih temeljnih izvorišta bračni i obiteljski život, tj. bračno i obiteljsko zajedništvo. To je temeljna razlikovna oznaka toga vida kršćanske duhovnosti. Taj život i to zajedništvo papa Franjo vidi presudnim za napredovanje na putu zajedništva s Bogom. $\gg$ Pozitivno iskustvo obiteljskog zajedništva pravi je put svakodnevnog posvećenja i mističnog rasta, sredstvo za dublje sjedinjenje s Bogom. $\ll^{45}$ Bračna i obiteljska duhovnost jest duhovnost nadnaravnoga zajedništva ostvarivanoga u konkretnom bračnom i obiteljskom okviru. Budući da je upravo taj okvir njezino nezamjenjivo uporište, potrebno je uvažavati značenje uzajamnoga predanja u svim njegovim bitnim sastavnicama i put svakodnevnoga posvećivanja i mističnoga rasta tražiti i pronalaziti

\footnotetext{
${ }^{40}$ Usp. EG, br. 11, 46, 73-74 i dr.

${ }^{41}$ Usp. Više o tome u: N. VRANJEŠ, (Ne)ostvarene koncilske teološko-pastoralne teme u hrvatskoj Crkvi. Pastoral i koncilska obnova danas, u: Bogoslovska smotra 83(2013.)1, 123.-124.

${ }^{42}$ Usp. AL, br. 204.

${ }^{43}$ Usp. isto, br. 203.

${ }^{44} \mathrm{U}$ broju 313 te pobudnice Papa se u tom smislu poziva na tekst iz dekreta Drugoga vatikanskoga koncila o apostolatu laika koji govori o nekim osobitostima duhovnosti vjernika laika; usp. DRUGI VATIKANSKI KONCIL, Apostolicam actuositatem. Dekret o apostolatu laika (18. XI. 1965.), br. 4, u: Dokumenti, Zagreb, ${ }^{7} 2008$.
}

${ }^{45} \mathrm{AL}$, br. 316. 
upravo u iskustvu obiteljskoga zajedništva. ${ }^{46} \mathrm{Tu}$ točku Papa u istom broju posebice dodatno naglašava i ističe jer očito mnogi imaju problema upravo s povezivanjem dubokih duhovnih težnji s konkretnim obiteljskim životom. U tome pogledu Papa ističe: $\gg$... duhovnost se utjelovljuje u obiteljsku zajednicu. Stoga, oni koji imaju duboke duhovne težnje ne smiju osjećati da ih obitelj sputava u njihovu rastu i napredovanju u duhovnom životu, nego je radije promatrati kao put koji Gospodin koristi da ih povede $\mathrm{k}$ vrhuncima mističnog sjedinjenja. $\ll{ }^{47} \mathrm{Na}$ taj se način u nekom pogledu još jednom pojašnjava pitanje odnosa duhovnoga i obiteljskoga života, tj. njihove unutarnje isprepletenosti i neodvojivosti. Time se ukazuje i na važnost izbjegavanja zamke dualističkoga poimanja kršćanskoga života i duhovnosti ili pak promatranja bračnoga i obiteljskoga života kao tobožnjih zapreka za dublji i bogatiji duhovni život.

Te tvrdnje izuzetno su važne i aktualne pogotovo uzme li se u obzir istinsku krizu življenja duhovnosti u braku i u obitelji; krizu koja se ne tiče tek pitanja zanemarivanja molitve i duhovnoga života, već uopće profiliranosti bračne i obiteljske duhovnosti kao načina konkretnoga življenja i ostvarivanja vjerskoga života. Naime, čini se da je u samoj Crkvi dobrim dijelom jasno da je duhovnost redovnika i redovnica te svećenika i donekle onih vjernika laika koji su se odlučili na služenje u trećim redovima ili sličnim oblicima apostolata po svojim specifičnim oznakama prepoznatljiva i određena. No s obzirom na bračnu i obiteljsku duhovnost, barem na široj crkvenoj razini, teško da možemo ustvrditi isto. Nadalje, ta se duhovnost često pokušava ostvarivati na različite načine, od kojih neki umnogome odudaraju od istinskoga crkvenoga viđenja duhovnosti u braku i obitelji. Tako se na primjer često može susresti poznati fenomen pokušaja ostvarivanja određenih (najčešće najbitnijih) elemenata duhovnoga života isključivo u crkvenom prostoru ili u strogo intimistički određenim privatnim prostorima, manje-više daleko od konkretnoga bračnoga i obiteljskoga zajedništva, tj. od svakodnevice. ${ }^{48}$ Takva nastojanja mogu imati različite uzroke, no njihove posljedice mogu ponekad biti prilično štetne za vjeru u braku i obitelji, a pogotovo za evangelizaciju u obitelji. Takve pojave uglavnom su vezane za odnos jednoga od supružnika prema drugom (najčešće žene prema mužu) ili pak za odnos roditelja prema djeci.

Kršćanska duhovnost nošena je sakramentima, molitvom, osobito onom zajedničkom obiteljskom. U njezinu konkretnom življenju pomažu i različiti oblici pučke pobožnosti. To je duhovnost isključive i slobodne ljubavi, isključive u odno-

\footnotetext{
${ }^{46}$ Usp. isto.

${ }^{47}$ Isto.

${ }^{48}$ Usp. Više o tome u: N. VRANJEŠ, (Ne)ostvarene koncilske teološko-pastoralne teme u hrvatskoj Crkvi, 127.-128.
} 
su na bilo koje treće osobe s obzirom na brak, a slobodne u smislu zauzimanja u pozitivnom smislu prema djeci, ali i bližnjima u potrebi. ${ }^{49}$ Bračni partneri trebaju, u prvome redu, jedno drugomu biti znak i oruđe blizine samoga Gospodina. $U$ tome pogledu duhovnost, poštujući načelo duhovnoga realizma, podrazumijeva zdravu autonomiju svake osobe jer je najintimnija sfera osobnosti podložna samo Bogu. $\mathrm{Na}$ takav način bračni partneri moći će uviđati da je savršena ljubav svojstvena samo Bogu. No za to je potrebno ući u proces duhovnoga oslobođenja. »Prostor koji svaki od supruga pridržava isključivo svomu osobnom odnosu s Bogom, ne samo da pomaže liječiti rane zajedničkog života nego također omogućuje supruzima naći u Božjoj ljubavi najdublji izvor smisla vlastitog života. Svaki dan moramo zazivati pomoć Duha Svetoga da ta unutarnja sloboda bude moguća. ${ }^{50}$

Nadalje, bračna i obiteljska duhovnost jest duhovnost skrbi, utjehe i poticaja. ${ }^{51}$ Upravo u obiteljskom ozračju duhovnost poprima posebno konkretne konture; ona se naime pretače u konkretnu skrb za bližnje, u prvom redu za novi život, tj. rađanje i odgajanje potomstva. »Život bračnoga para svakodnevno je dioništvo u Božjem plodonosnom djelovanju, a svaka je osoba za drugu stalni izazov Duha Svetoga. $\ll^{52} \mathrm{U}$ tome pogledu druga je osoba poziv na pomaganje u ukupnom unaprjeđenju i postizanju najboljega što može. Otvorenost i sloboda temeljni su preduvjeti za takav pogled na drugu osobu, a poštovanje njezina dostojanstva nezaobilazna sastavnica duhovnosti prožete istinskim milosrđem. Takvo poimanje i življenje duhovnosti u braku i obitelji pretače se potom u gostoljubivost kao izraz skrbi za sreću drugih osoba (a osobito siromašnih) te u različite druge oblike tzv. socijalne ljubavi.

Riječ je ovdje u biti o duhovnosti otvorenosti koja podrazumijeva stalan napredak na putu sazrijevanja. Obitelj uvijek treba rasti u sposobnosti ljubiti. Iako je duhovnost prožeta pozivom na puninu života i ljubavi, tu puninu ipak možemo očekivati samo s one strane života, na drugoj obali. Do tada ostaje hod za koji Papa, pozivajući same obitelji, zaključno ističe: $\gg$ Hodajmo obitelji, nastavimo taj hod! Ono što nam je obećano veće je nego što možemo zamisliti. Nikada ne izgubimo nadu zbog naših ograničenja, ali ni ne odustajmo od toga da tražimo puninu ljubavi i zajedništva koje nam je Bog obećao. ${ }^{53}$

\footnotetext{
${ }^{49}$ Usp. AL, br. 319.

${ }^{50}$ Isto, br. 320.

${ }^{51}$ Usp. isto, br. 321.

${ }^{52}$ Isto.

${ }^{53}$ Isto, br. 325.
} 


\section{Zaključak}

Apostolska pobudnica Amoris laetitia pape Franje u teološko-pastoralnom smislu obiluje novim uvidima, produbljivanjima i prijedlozima za konkretan angažman obitelji i crkvene zajednice u pogledu skrbi za brak i obitelj danas. Elementi, etape i perspektive pastorala braka $i$ obitelji na poseban su način obrađene $u$ šestom poglavlju toga dokumenta pod naslovom Neke pastoralne perspektive. Uz njihovo teološko-pastoralno razlučivanje u ovom smo se radu posvetili i razlučivanju teme duhovnosti u braku i obitelji koja je obrađena u završnom, devetom poglavlju toga dokumenta naslovljenom Bračna i obiteljska duhovnost.

U prvome izdvojenome podnaslovu Papa se dotiče razlučivanja svih važnih sastavnica pastorala braka i obitelji počevši od priprave za brak, preko praćenja mladih bračnih parova, pitanja kriznih situacija, teme komunikacije u obitelji, pitanja odnosa prema tzv. neredovitim i neregularnim situacijama, teme braka u starosti i, konačno, teme perspektiva u tom području djelovanja. U drugome izdvojenome podnaslovu posebno se osvrće na pitanje identiteta i izvorišta bračne i obiteljske duhovnosti, njezine ukorijenjenosti u molitvenom i sakramentalnom životu, ali i njezine socijalne usmjerenosti. Kao jednu od niti vodilja tih poglavlja, ali i cijele pobudnice, niti koja objedinjuje cijeli dokument, u teološko-pastoralnom i duhovnom smislu treba istaknuti Papin poziv obiteljima na rast i sazrijevanje u sposobnosti odgovorne ljubavi. Papa Franjo upravo nastojanje u tom rastu i sazrijevanju vidi ključnim za uspjeh i održivost, ali i sreću i radost zajedničkoga bračnoga i obiteljskoga života. Tom nastajanju Crkva treba pružiti svu moguću pomoć i podršku kroz svoje pastoralno djelovanje. 


\title{
ELEMENTS, STAGES AND PERSPECTIVES OF THE MARRIAGE AND FAMILY PASTORAL CARE ACCORDING TO THE APOSTOLIC EXHORTATION AMORIS LAETITIA
}

\author{
Nikola VRANJEŠ*
}

Summary: This paper is dedicated to the theological-pastoral elaboration of the question of approaching the elements, stages and perspectives of the marriage and family pastoral care in the post-synodal apostolic exhortation of Pope Francis Amoris Laetitia, with special attention being paid to the subject of marital and family spirituality. The marriage and family pastoral care is one of the most difficult areas of church activity today. In the exhortation, Pope Francis looks at it from a broader perspective by framing it into a contemporary social and pastoral context. In this regard, the Pope also elaborates certain, we could say, priority tasks which the Church today has been called to realize more strongly in this area of its activities. Regarding the elements, stages and perspectives of the marriage and family pastoral care, and the family spirituality, we examine these tasks and priorities in the paper by following the order and the dynamics of developing the themes present in the exhortation itself, while keeping in mind some of the challenges from the pastoral situation in Croatia.

Keywords: pastoral, marriage, family, preparation, spirituality, Church, Pope Francis.

\footnotetext{
* Asst. Prof. Nikola Vranješ, Ph. D., Theology of Rijeka, Dislocated Studies of Catholic Faculty of Theology, University of Zagreb, Omladinska 14, 51000 Rijeka, Croatia, nickvranjes@yahoo.com
} 